\title{
HUMAN RESOURCES MANAGEMENT EFFECTIVENESS FROM A MULTILEVEL PERSPECTIVE ${ }^{a}$
}

\author{
Magdalena Majowska 1 (1) http://orcid.org/0000-0003-2434-402X \\ Agata Austen2 http://orcid.org/0000-0002-1362-2736
}

\begin{abstract}
Background. Although it was proved that there is a positive relationship between effectiveness of HRM and performance of the organization, little is known why this relationship exists. It is due to the focus on the organizational level, instead of examining behavioral aspects of individuals in the organizations.
\end{abstract}

Research aims. The aim of presented article is to fill the gap in HRM effectiveness research by applying multilevel approach. A literature review was conducted to examine how HRM effectiveness was linked to other variables in previous research according to the multilevel logic.

Methodology. The article uses systematic literature review of the empirical research on HRM effectiveness focusing on its antecedents and outcomes.

Key findings. The review revealed scarcity of multilevel approach towards HRM effectiveness yet suggests there is a gap in examining antecedents and outcomes on individual or unit/ group level of analysis.

Keywords: HRM effectiveness, SHRM, multilevel approach, literature review JEL Codes: M12, C18, L29

\section{INTRODUCTION}

The human resource management (HRM) has evolved into a strategic partner. This has led to the emergence of the concept of strategic human

${ }^{a}$ This article is a result of a research project financed by National Science Centre (grant number: 2015/19/D/HS4/00 805)

* Department of Human Resources Management, University of Economics in Katowice.

E-mail: magdalena.majowska@ue.katowice.pl.

** Department of Human Resources Management, University of Economics in Katowice. E-mail: agata.austen@ue.katowice.pl. 
resource management (SHRM). Although plethora of research in SHRM links HRM to performance, little is known why and how SHRM enhances organizational outcomes.

One way to answer this question is to focus on HRM effectiveness instead, as there is evidence that organizational performance is likely to be influenced not just by HR practices but by more proximal measures, for example, effectiveness of HRM function (Teo, 2000). Effective HRM can be described as an important catalyst in accomplishing organizational performance, because it can help to attract and retain qualified human resources, motivate people for better work, develop the skills and competencies of employees, and create firm value through the selection, development and use of human capital (Lepak \& Snell, 1999). Empirical research in strategic HRM has made considerable progress in linking bundles of human resource (HR) practices and firm performance, yet our understanding of the mediating mechanisms or processes through which HR practices influence firm performance remains still limited. The reason is the lack of consensus regarding the mechanisms by which HR practices might impact on firm outcomes. It results in limited although growing number of empirical studies that explore the processes through which this impact takes place (Jiang et al., 2012).

The second proposal is to turn the attention to the multilevel research. There has been a rapid growth in multilevel research in management and attempts to bridge the gap between micro (i.e. individual) and macro (i.e. organizational) phenomena and levels of analysis. The spread of the multilevel approach has been uneven across different subdomains of management. Examining the relationship between organizational levels allows to understand the system as a whole and limits the misunderstandings that could result from ignoring the effects between different levels. From a theoretical point of view, omission of multiple levels can lead to erroneous models (Rousseau, 1985). In addition, actions taken at one level of analysis can have unintended consequences at other levels. Moreover, practitioners are interested in solving problems at all levels of analysis, and research that presents partial solutions to problems (i.e. taking into account only the micro or macro perspective) is considered to be of little use (Aguinis et al., 2011). Specialization and fragmentation in the management field usually lead to separate, oversimplified studies that are different from real and complex problems. The real problems faced by companies and 
managers usually relate to phenomena at different levels. For example, a human resources management system can influence employees' behavior at the individual level, which in turn can also influence both firm and individual performance (Molina-Azorín et al., 2019).

This paper aims at filling the gap in HRM effectiveness research by linking this concept to multilevel approach. First, as in the field of management, and the same human resource management (HRM), multilevel approach has been applied rarely, we explain the idea and rules of multilevel approach. Next, we present the review of the empirical research on HRM effectiveness focusing on its antecedents and outcomes. Finally, we discuss the challenges for future research in HRM effectiveness.

\section{BASIC PRINCIPLES OF MULTILEVEL RESEARCH}

Kozlowski and Klein (2000) presented central principles of multilevel theory building and research organized around the what, how, where, when, and why (and why not) of multilevel theoretical models. In particular, it is necessary to consider:

1. On what should multilevel theory building and research focus? What phenomenon is the theory and research attempting to understand?

2. Theoretical model must specify how phenomena at different levels are linked (top-down or bottom-up).

3. Where do top-down and bottom-up processes originate and culminate? The answers to these questions specify the focal entities-the specific organizational levels, units, or elements-relevant to theory construction.

4. Many organizational phenomena are influenced and shaped by time, which can be treated as boundary condition or moderator or may impose using time-scale variations across levels.

5. Why are relationships in the model conceptualized as top-down rather than bottom-up? Why are constructs conceptualized as compositional rather than compilational? Why are predictors assumed to have immediate rather than long-term consequences for the outcomes of interest?

Many of the challenges associated with multilevel research are based on misspecifications or misalignments among the theoretical 
level of constructs, their measurement, and their representation for analysis (Rousseau, 1985). Constructs are the building blocks of organizational theory. A construct is an abstraction used to explain an apparent phenomenon. The level of a construct is the level at which it is hypothesized to be manifest in a given theoretical model-the known or predicted level of the phenomenon in question. In multilevel research, the theoretical explanation will span several levels in the effort to understand an endogenous construct at a given focal level. The first and foremost task in crafting a multilevel theory or study is to define, justify, and explain the level of each focal construct that constitutes the theoretical system. Yet, the level of many organizational constructs is unclear. E.g. climate was to be conceptualized and measured both as an organizational (unit) construct or as a psychological (individual) one. Many phenomena that take place in organizations have their theoretical origins in the cognition, affect, and behavior of individuals but emerge, through compositional or compilational processes, to manifest as higher-level phenomena.

The level of measurement is the level at which data are collected to assess a given construct. When the level of measurement is lower than the level of analysis, the researcher needs to justify aggregation the data and provide a theoretical rationale that explains how the higher level phenomenon comes into existence. The more general point about measurement in multilevel investigations is that researchers need to have a theory about how data collected at one level of analysis should be combined to represent constructs at a higher level of analysis. Generally speaking, there are two types of aggregation principles: composition and compilation (Kozlowski \& Klein, 2000). Composition refers to situations where descriptive statistics, such as means or sums of scores in a collective, adequately represent the processes that associate lower-level data with higher-level constructs. For example, one might use the average of individuals' knowledge, skills, and abilities to represent organizational human capital. In other instances, one might employ some form of variance index to represent an aggregate construct, such as demographic or functional diversity. On the other hand, compilation refers to situations where measures collected from lower-level entities combine in nonlinear, complex ways to generate a gestalt, or whole not reducible to its constituent parts. Compilation processes describe the combination of related but different lower-level properties-that is, the configuration of different lower-level 
characteristics to yield a higher-level property that is functionally equivalent to its constituent elements. In consequence, individual-level constructs should, of course, be assessed with individual-level data. Unit-level constructs, in contrast, may be assessed with either unit level or individual-level data. When unit-level constructs are assessed with unit-level measures, an expert source (a subject matter expert, for example, or an objective archive) provides a single rating of each unit. When unit-level constructs are assessed with individual-level measures, unit members provide individual-level data (for example, individual ratings of climate, or individuals' reports of their own demographic characteristics), which are subsequently combined in some way to depict the unit as a whole. The way in which construct is measured will be different for global properties of a unit (observable, descriptive characteristics of a unit, they do not emerge from individual-level experiences, attitudes, values, or characteristics), shared properties of a unit (they emerge from individual members' shared perceptions, affect, and responses) or configural properties (the data to assess the construct derive from the characteristics, cognitions, or behaviors of individual members).

The level of analysis is the unit, to which data is assigned to conduct statistical analyses and test the hypothesis. It should be subordinated to the level of theory used for the construct being studied. When the levels of theory and measurement are not aligned with the level of analysis problems related to fallacies of the wrong level may occur. However, the level of measurement may differ from the level of analysis when an adequate process of aggregation is implemented. For example, several employees of a firm indicate their individual perceptions about the organizational culture (measurement at the individual level). If we want to analyze the influence of organizational culture on another organizational variable (for example, firm performance) and, therefore, the analysis is at the organizational level, we must aggregate the individual perceptions of culture to create a variable at the organizational level. But, as indicated above, this aggregation must be justified both theoretically (processes that relate the two levels) and statistically (examining whether there is some agreement in individual assessments) (Kozlowski \& Klein, 2000). It is wort to emphasize distinctiveness of analysis methods for multilevel data, such as: within and between analysis (WABA), intraclass correlation coefficient 1-ICC (1), random coefficients modeling (RCM) including 
hierarchical linear modeling (HLM) and multilevel versions of structural equation modeling techniques (ML-SEM) (Hitt et al., 2007).

Another key aspect of multilevel research is the existence of dependence (or lack of independence) among the observations/ measurements considered, as a consequence of nested structures (students and classrooms, workers and work groups, companies and industries, repeated measurements in longitudinal data). For example, in studies about performance of individual workers (dependent variable, level 1) considering as independent variables both individual characteristics of these employees (level 1) and organizational aspects (level 2), the fact that different employees constitute the same organization implies that they share the same context variables of the organization (for example, strategy). In addition, they interact with each other and this can also imply similarities in terms of performance of the employees (Molina-Azorín et al., 2019).

It is worth to notice, that multilevel studies are not a homogeneous group. They can be implemented using various models: cross-level models, composition models, and homologous multilevel models.

Composition models reflect the functional relationships among phenomena or constructs at different levels of analysis that are nondependent yet functionally similar. These models do not necessarily need to postulate isomorphism of constructs. The example can be individual and group learning; although involve similar psychological process, the individual and group learning curve differ (Rousseau, 1995).

Cross level models specify causal models of the effect phenomena at one level on those at another. They may take three forms: (1) cross-level direct-effect models predict the direct effect of a higher-level construct on a lower-level, variants of cross-level direct-effect models include mixed-determinant and mixed-effect models, (2) cross-level moderator models suggest that the relationship between two lower-level constructs is changed or moderated by a characteristic of the higher-level entity in which they are both embedded, (3) cross-level frog-pond models highlight the effects of a lower-level entity's relative standing within a higher-level entity, they investigate comparative processes (individual differences from group standards, where $\mathrm{x}$, calculated as X- an average $\mathrm{X}$, is the independent variable) (Kozlowski \& Klein, 2000).

Finally, homologous models assume formal identity among constructs at different levels. There are two main assumptions underlying homologous models. The first is that the constructs in the models maintain 
theoretical similarity across levels of analysis. For instance, in a test of homology across levels involving a construct such as efficacy, one must accept that self-efficacy (an individual construct) and collective efficacy (a group-level construct) maintain enough theoretical similarity across levels to make a contrast of their correlates meaningful. The second concerns whether X-Y relationships observed at one level of analysis are comparable to those obtained between similar variables at different level of analysis. Examples of theoretical homologous models include the threat-rigidity hypothesis or the efficacy-performance spirals model. Earlier work on homology suggested that the structural equivalence across levels could be investigated based on what might be referred to as loose evidence of construct isomorphism - similarity or one-to-one correspondence between two or more elements. However, there is a growing realization today that informal approaches to isomorphism are better replaced by formal modeling approaches that test this assumption (Guenole, 2016).

\section{THE IDEA AND RATIONALE OF CONDUCTING MULTI- -LEVEL RESEARCH IN SHRM}

The groundbreaking work The Principles of Scientific Management by Taylor (1911) presented a reflection on how the activities and results of employees are related to the performance of the organization, thereby underlying the multilevel nature of managerial problems. However, as the discipline evolved, the research started to be conducted at either the at the micro (e.g. organisational behaviours) or macro level (e.g. management theory) (Aguinis et al., 2011). In the early 1980 s, researchers of organization and management again pointed to the dependence of organization's results on determinants at different levels of organization (House et al., 1995; Rousseau, 1985). Theories at the macro level focus on explaining organisational phenomena, omitting the individual level, while it is individuals who shape these phenomena. On the other hand, micro theories focus exclusively on the attributes and behaviors of individuals and small groups (House et al., 1995). This dichotomy limits the full understanding of behavior at each level and leads to a multiplication of various research paradigms. Undoubtedly, the diversity of paradigms brings many benefits, 
but from the point of view of scientific development, the synthesis of paradigms is also valuable (cf. Pfeffer, 1993; Rousseau, 2000).

Multilevel modeling was first used in education and marketing research. HRM research has lagged behind in the application of this statistical technique as the majority of HRM research has historically been conducted at the single level of analysis. One of the reasons for this is a lack of theorization of the hierarchal nature of HRM practices (Shen et al., 2018). Integrating levels of analysis in HRM area, grew out of two ideas. First, it has been proved that organizational HRM policies influence organizational performance, yet it includes affecting lower-level variables such as individual-level attitudes and behaviors. Second, these relationships between two levels impose to treat strategic HRM (SHRM) as a multilevel phenomenon (Renkema et al., 2017). It should also be noticed that also some phenomena, as emotions in organization, are multilevel in nature (Ashkanasy et al., 2017).

According to multi-level logic, individuals are nested in larger structures (House et al., 1995). Individuals in the organisation are members of working groups that form larger organisational units (departments, strategic business units) that create the organisations. These, in turn may be part of inter-organisational networks. In line with the idea of a multi-level approach, also called meso approach, organizations influence the behaviour of individuals and the behaviour of individuals shapes the behaviour of organisations. For example, the structure of an organization determines the flow of information, thus influencing the decision-making process of managers. Structural aspects of hierarchical systems determine the distribution of power in the organization, stimulating the use of power. Organizational processes, on the other hand, can actually be perceived as behaviours of individuals, and individuals shape organizational processes: for example, leaders formulate a strategy, and organizational culture is the result of the characteristics, beliefs or emotions of individuals (House et al., 1995). Applying multilevel models to HRM area enables to explain how lower-level entities, such as employees or teams, become aligned with higher-level entities such as organizational goals as due to the hierarchical nature of organizations, the majority of organizational problems are multilevel level in nature (Renkema et al., 2017).

Strategic human resource management (SHRM) aligns HR decisions with the strategy and horizontal coordination of HRM practices. The field is focused on the HRM - performance relationship. At the beginning 
research in this stream related to the organizational level of analysis, yet in more recent research, individual level has been also considered (Wright et al., 2018). The fact that individuals in organizations people are becoming central to strategic decision-making seems reasonably unarguable. SHRM researchers have provided evidence that the ways in which people are managed, particularly through HR practices, have strong empirical relationships with organizational performance. Yet many researchers have criticized the theoretical underpinnings of the research and called for more specific and complex theoretical models of the processes through which HR practices impact organizational performance, including involvement of individual level phenomena within the causal chain (Wright \& Haggerty, 2005). That is why blending research on the individual employee level (typical OB studies) with research at the organisational level (typical SHRM studies) (Wright \& Boswell, 2002) is necessary.

Researchers increasingly recognize the requisite multilevel nature of SHRM field. For instance, most studies of the relationship between HRM practices and performance examine the HRM practices for a job or group of jobs within the organization. Thus, whether measured as the report of an HR manager or the aggregated measure of several employees' reports, the HRM practice measure represents the practices for an organization. This measure then is correlated with an organization-level measure of performance. However, each practice affects individuals who perceive the practice, evaluate the practice, and react to the practice affectively and behaviorally. So the link between the organization-level practice and organization-level performance must take place through individuals (Wright \& Ulrich, 2017). As Wright and Ulrich (2017) claim, although studies can still focus singularly on one or another of these levels of analysis, research in this area will probably increasingly trend toward multilevel. They propose that SHRM research could develop theoretical models that describe multilevel phenomenon through emergence processes and use different levels to test multilevel and cross-level effects (e.g. individual-unit, unit-organization, organization-industry, organization-national). 


\section{HRM EFFECTIVENESS IN EMPIRICAL RESEARCH}

HRM effectiveness is a broad construct, described in different ways. Generally speaking this notion demonstrates HRM effectiveness as being a level of "human resource management satisfaction with various human resource activities" (Huselid et al., 1997). It refers to "the value of what HR professionals do for the rest of the organization, and how HRM practices are linked to desired organizational outcomes" (Ruël et al., 2007). More specifically, HRM effectiveness may be characterized "as the extent to which the operations manager felt that the department performed well, met his or her expectations, and was a value added/bottom line contributor to the business" (Wright et al., 1998). Researchers dealing with HRM issues point to many contextual factors that may shape (decrease or increase) the effectiveness of HRM. Analyses are also complicated by the fact that there is no single, comprehensive measure of HRM effectiveness (Ryu \& Kim, 2013). This situation makes the understanding of the mechanisms underlying the effectiveness of HRM quite fragmentary (Huff \& Schüssler, 2016) and requires further study.

To examine how HRM effectiveness was linked to other variables in previous research we conducted a literature review. In order to identify empirical studies presenting the concept of HRM effectiveness the articles in scientific journals available in Ebsco and Proquest databases were reviewed. The following keywords have been identified to search the databases: HRM effectiveness, HR effectiveness, HPWPs effectiveness, personnel management effectiveness. The next stage included the analysis of abstracts in order to determine whether the article was theoretical or presented the results of empirical research. After identification of potentially related articles, they were analysed in terms of HRM effectiveness measurement method, antecedents and outcomes of HRM effectiveness. Thirty-five articles were finally analyzed. The results of the analysis are presented in Table 1.

In the SHRM literature there is a strong theoretical assumption and empirical evidence that HRM contributes to the achievement of desired outcomes at the organizational level (Huselid, 1995). This is reflected in research on HRM effectiveness, which focuses mainly on the organizational level and treats this notion as a strategic success factor, which enables organizations to increase their effectiveness, 


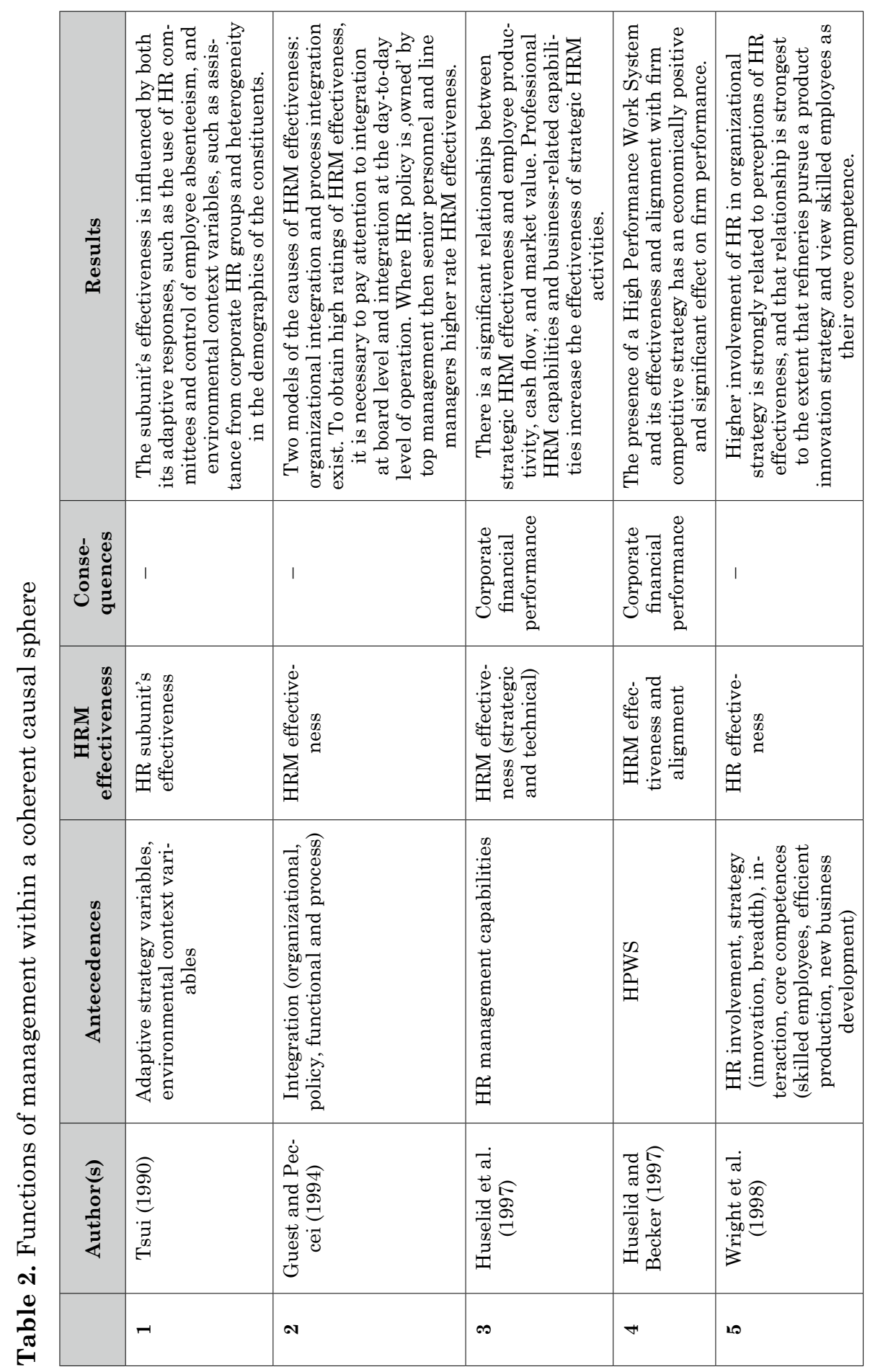




\begin{tabular}{|c|c|c|c|c|c|}
\hline 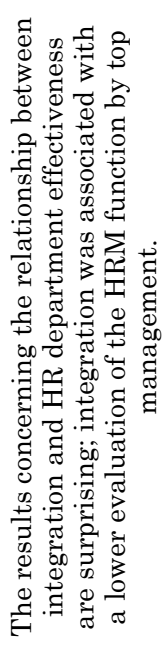 & 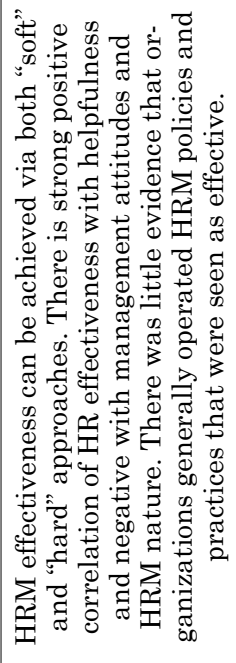 & 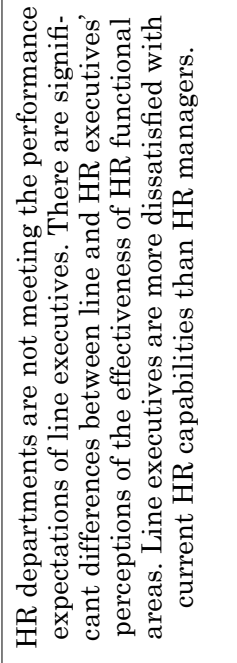 & 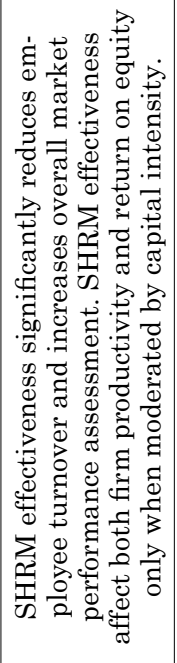 & 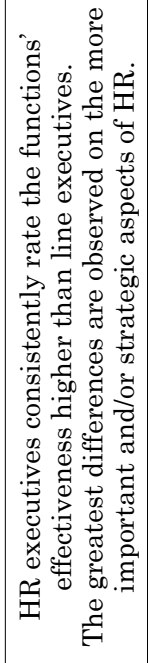 & 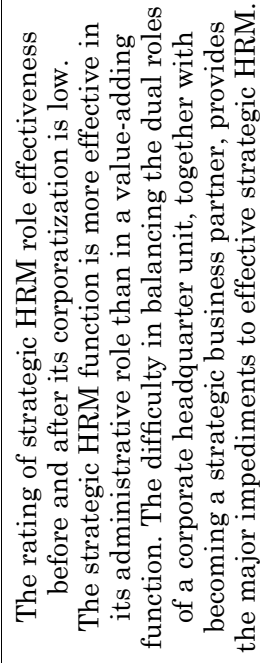 \\
\hline 1 & 1 & 1 & 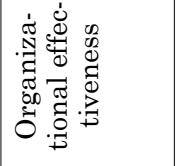 & 1 & 1 \\
\hline 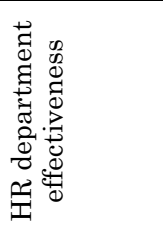 & 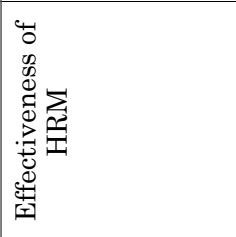 & 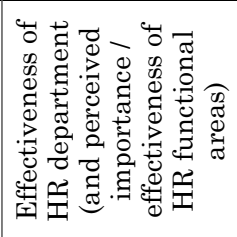 & 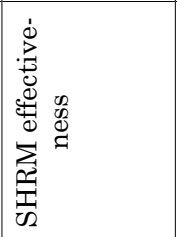 & 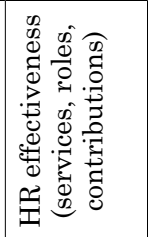 & 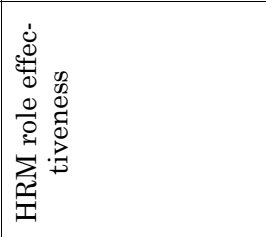 \\
\hline 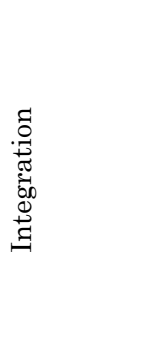 & 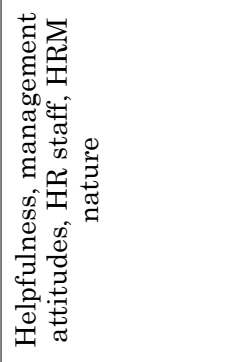 & 1 & 1 & 1 & 1 \\
\hline 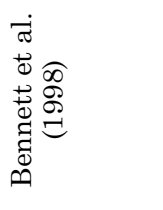 & 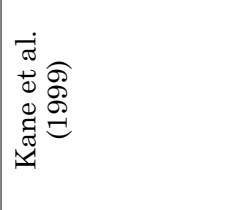 & 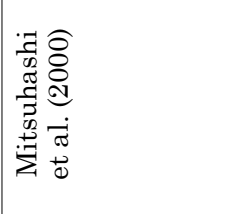 & 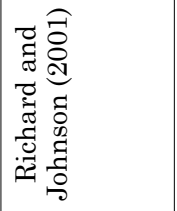 & 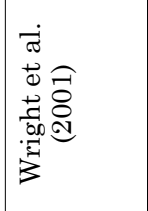 & 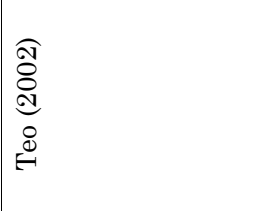 \\
\hline 0 & $r$ & $\infty$ & 0 & $\stackrel{9}{\circ}$ & $z$ \\
\hline
\end{tabular}




\begin{tabular}{|c|c|c|c|c|c|}
\hline 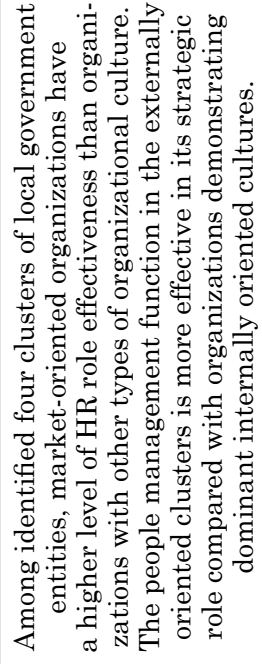 & 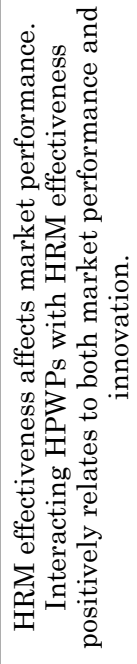 & 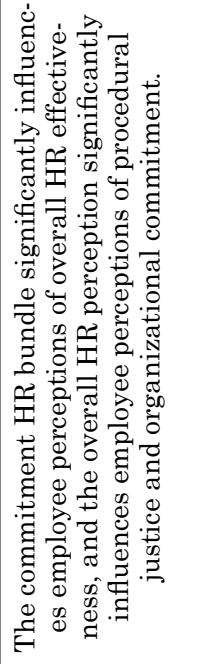 & 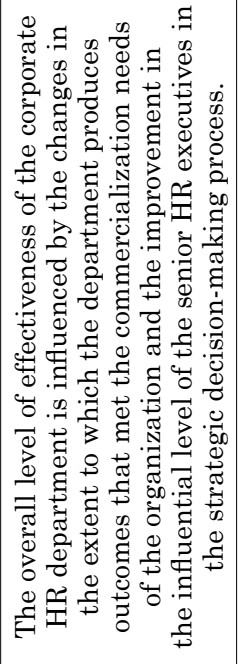 & 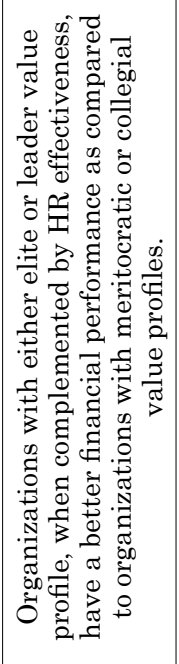 & 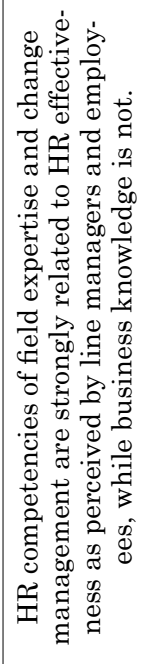 \\
\hline 1 & 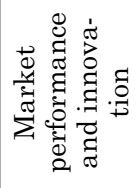 & 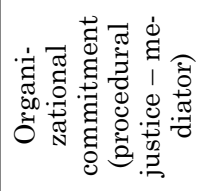 & 1 & 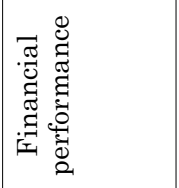 & 1 \\
\hline 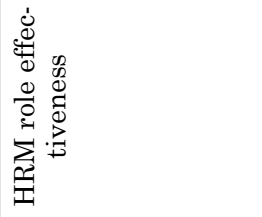 & 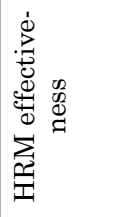 & 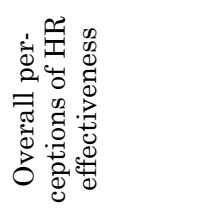 & 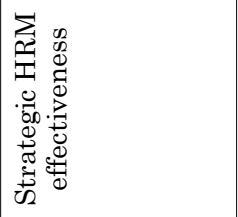 & 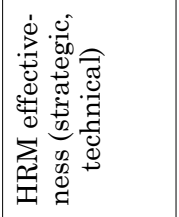 & 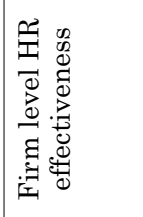 \\
\hline 1 & 1 & 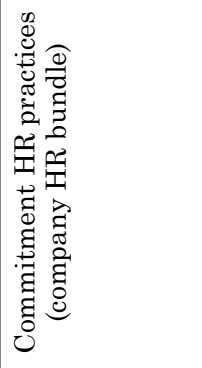 & 1 & 1 & 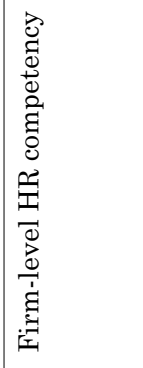 \\
\hline 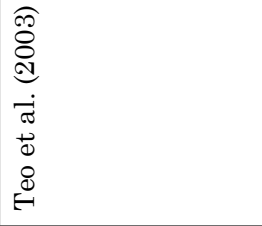 & 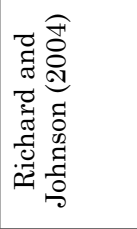 & 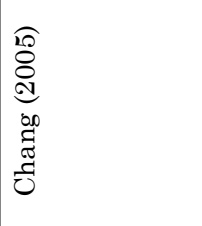 & 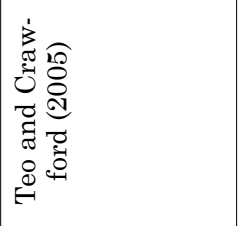 & 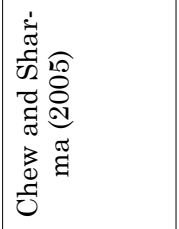 & 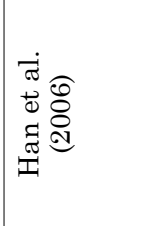 \\
\hline$\stackrel{\stackrel{\sim}{\sim}}{\sim}$ & $\stackrel{\infty}{\sim}$ & 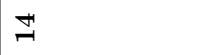 & $\stackrel{10}{\sim}$ & $\stackrel{0}{-}$ & $\approx$ \\
\hline
\end{tabular}




\begin{tabular}{|c|c|c|c|c|c|}
\hline 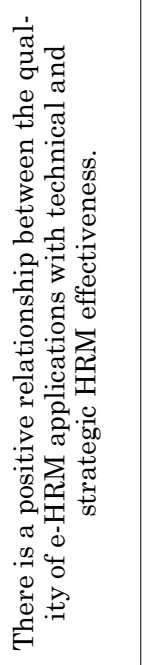 & 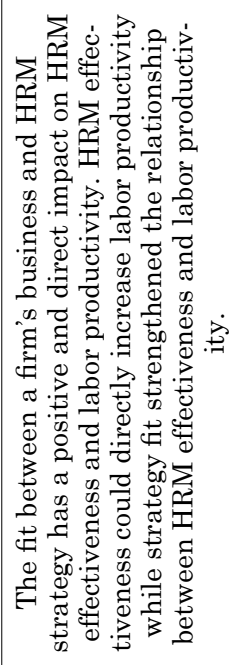 & 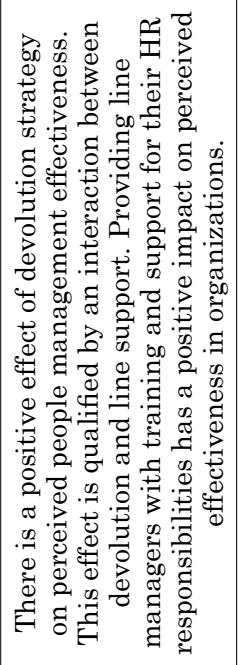 & 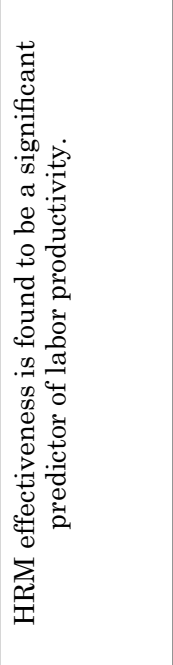 & 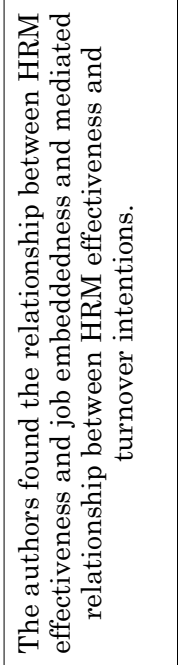 & 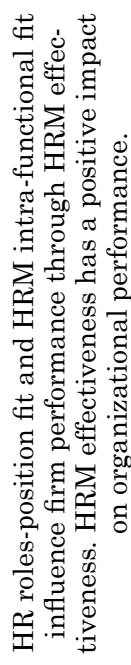 \\
\hline 1 & 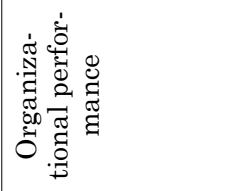 & 1 & 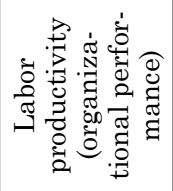 & 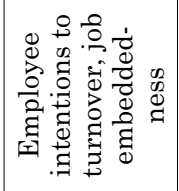 & 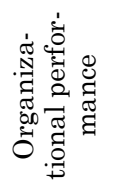 \\
\hline 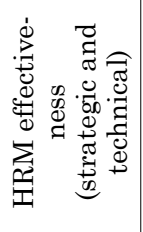 & 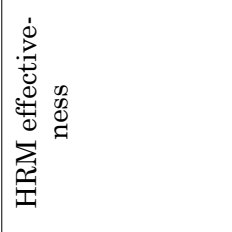 & 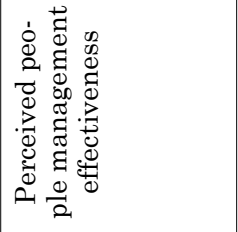 & 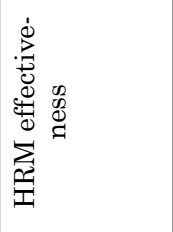 & 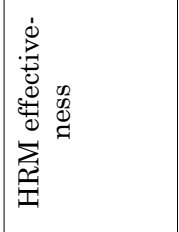 & 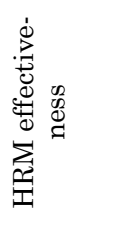 \\
\hline 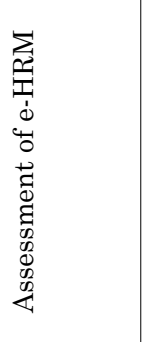 & 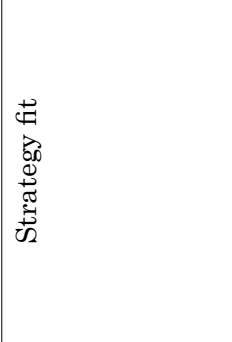 & 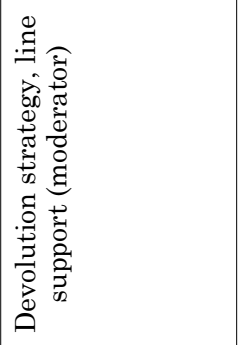 & 1 & 1 & 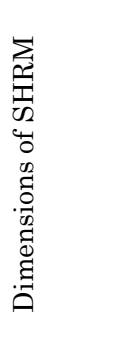 \\
\hline 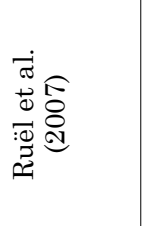 & 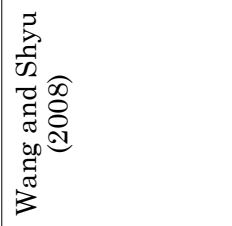 & 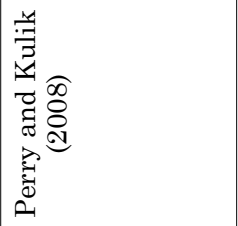 & 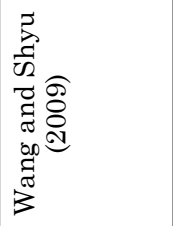 & 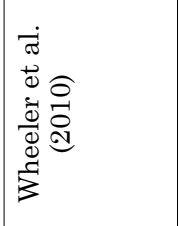 & 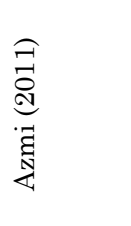 \\
\hline 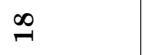 & - & ส & $\vec{a}$ & N & N \\
\hline
\end{tabular}




\begin{tabular}{|c|c|c|c|c|c|}
\hline 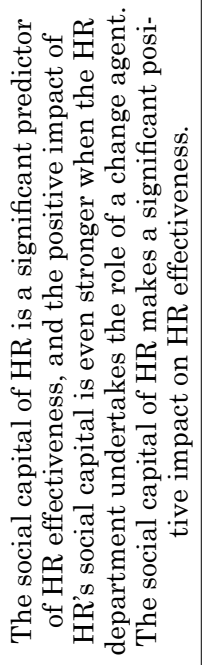 & 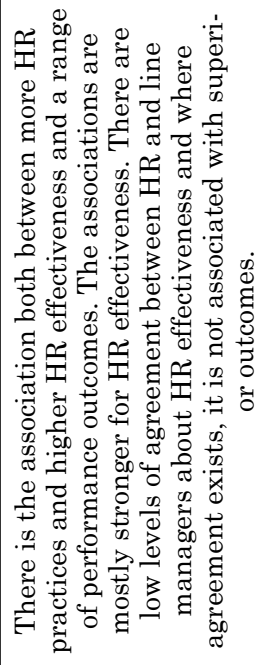 & 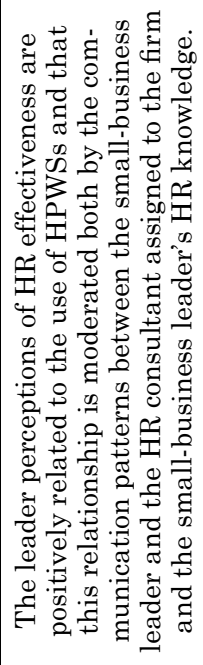 & 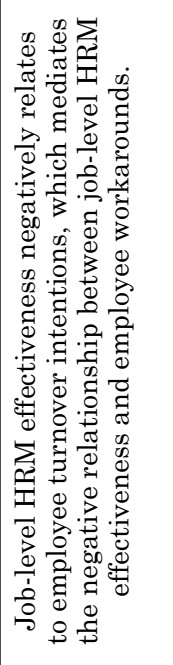 & 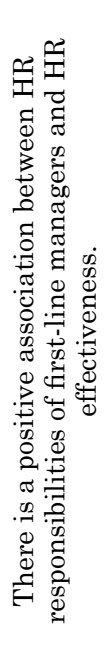 & 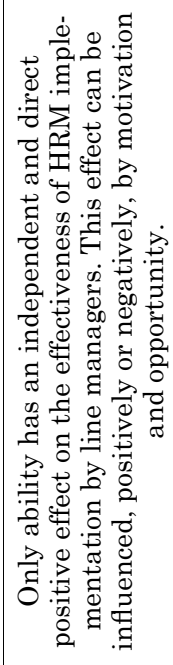 \\
\hline 1 & 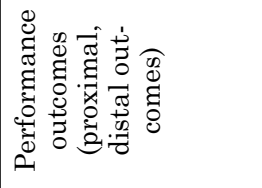 & 1 & 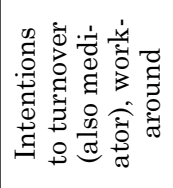 & 1 & 1 \\
\hline 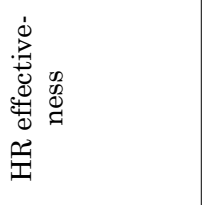 & 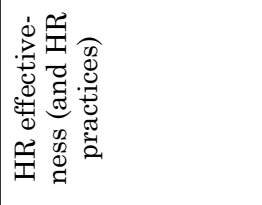 & 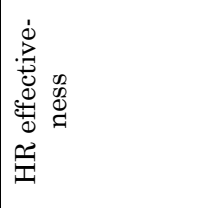 & 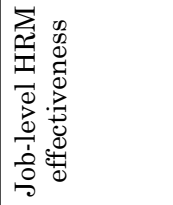 & 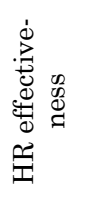 & 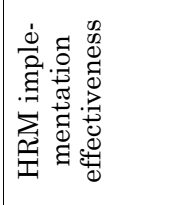 \\
\hline 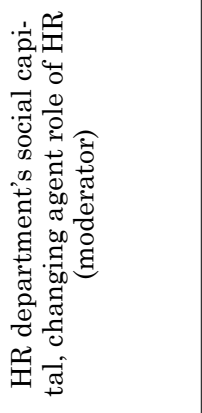 & 1 & 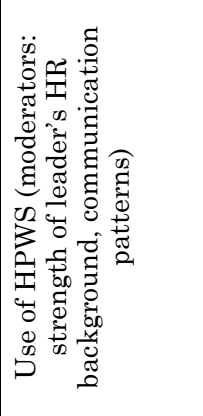 & 1 & 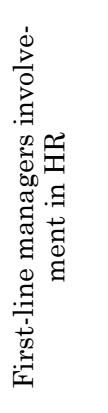 & 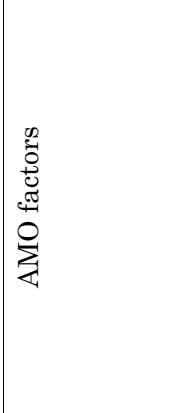 \\
\hline 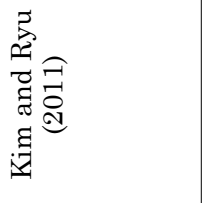 & 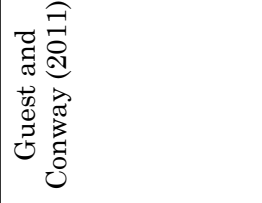 & 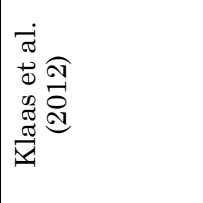 & 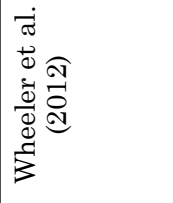 & 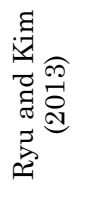 & 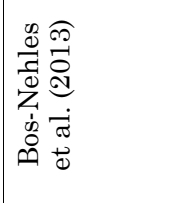 \\
\hline$\vec{N}$ & ลง & N & N & N & N \\
\hline
\end{tabular}




\begin{tabular}{|c|c|c|c|c|c|}
\hline 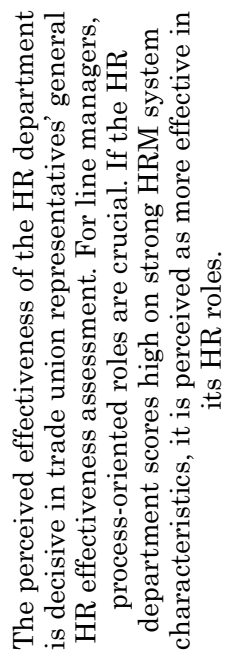 & 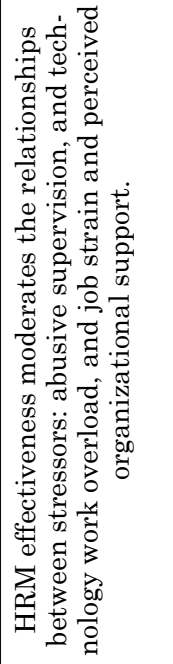 & 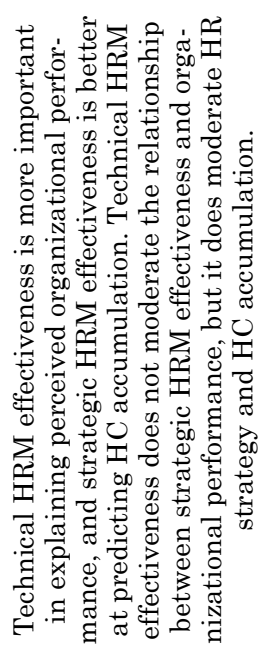 & 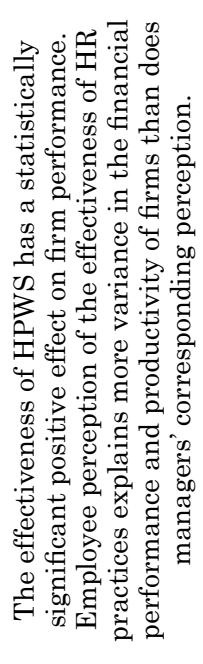 & 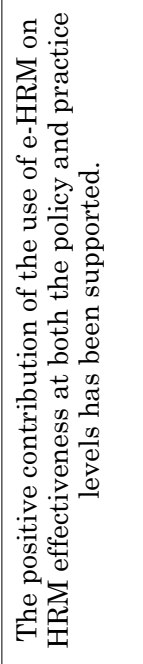 & 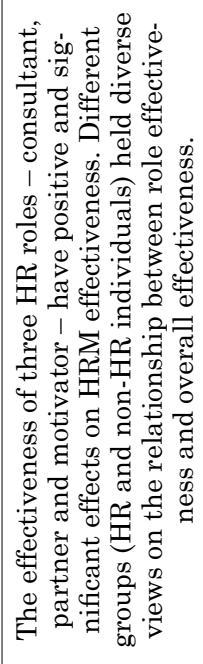 \\
\hline 1 & 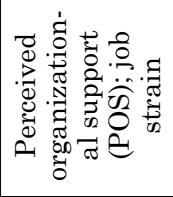 & 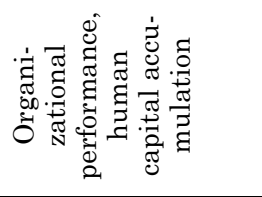 & 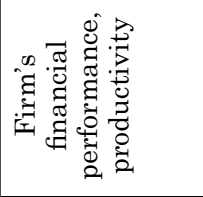 & 1 & 1 \\
\hline 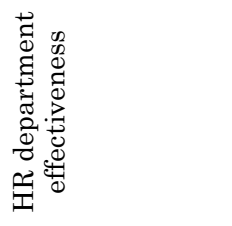 & 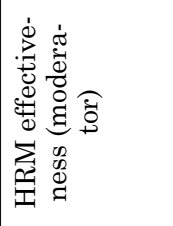 & 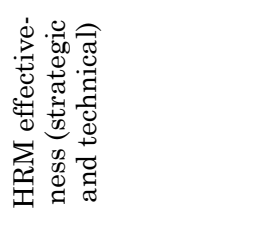 & 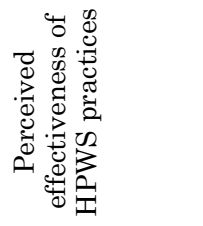 & 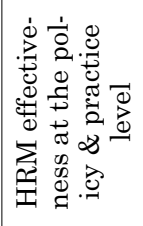 & 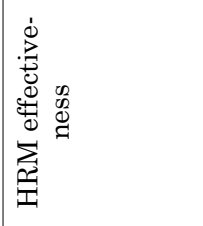 \\
\hline 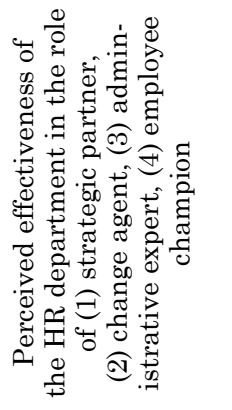 & 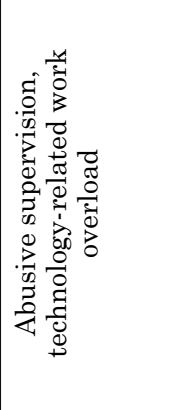 & 1 & 1 & 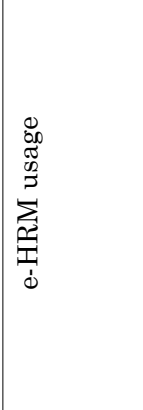 & 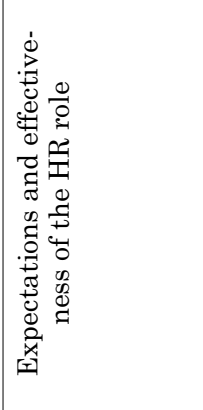 \\
\hline 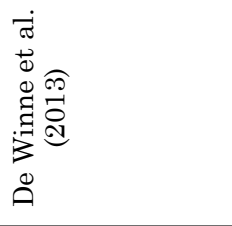 & 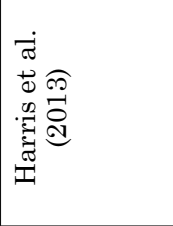 & 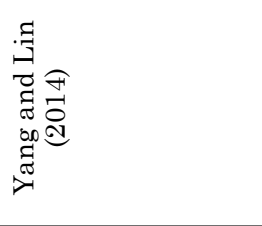 & 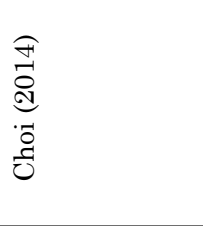 & 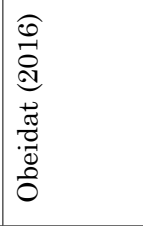 & 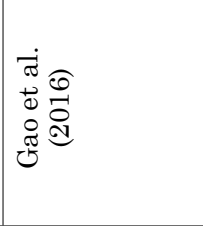 \\
\hline లి & $\vec{\infty}$ & ช้ & $\mathscr{m}$ & है & 20 \\
\hline
\end{tabular}


and thus gain a competitive advantage (Huselid et al., 1997; Richard \& Johnson, 2001; Ruël et al., 2007). For this reason, most of the HRM effectiveness outcomes or consequences is analyzed at the firm level and included variables related to organizational performance and outcomes. These studies therefore do not qualify as multi-level studies. Among fifteen papers presenting results/consequences of HRM effectiveness (Table 1), only three of them examined following outcomes at the individual level: employee intentions to turnover, job embeddedness, workaround, organizational commitment and procedural justice (Chang, 2005; Wheeler et al., 2010; Wheeler et al., 2012) and thereby can be regarded as multilevel research. In one research (Harris et al., 2013) HRM effectiveness moderated the relationships between stressors at organizational level (abusive supervision and technology work overload) and outcomes at the individual level (job strain and perceived organizational support).

Not only HRM consequences, but also the HRM effectiveness construct itself is analyzed mainly at one level - at the HR department and (sub)unit level (Tsui, 1990; Bennett et al., 1998; Mitsuhashi et al., 2000; De Winne et al., 2013) or at the firm level (Han et al., 2006). Some researchers take into account two different levels of HRM effectiveness, e.g. strategic and technical (Huselid et al., 1997; Chew \& Sharma, 2005; Ruël et al., 2007; Yang \& Lin, 2014) or policy and practice levels (Obeidat, 2016). Huselid et al. (1997) distinguish between two types of effectiveness: (1) technical HRM effectiveness, which engages using traditional HR practices efficiently, (2) strategic HRM effectiveness, which involves building human resource complexities through innovations such as team-based job designs, flexible workforces and employee empowerment. In contrast, Obeidat (2016) indicates that at the policy level of HRM effectiveness could be explained by the strength of the HRM system (Bowen \& Ostroff, 2004), which ensures effective implementation of intended HRM practices (Wright \& Nishii, 2013). Despite taking into account two different dimensions of HRM effectiveness, these studies were not conducted according to the methodology of multilevel studies.

Finally, HRM effectiveness antecedents were examined mainly at the organizational level. Only social capital of HR department employees (Kim \& Ryu, 2011) and front-line managers (FLMs') involvement in HR (Ryu \& Kim, 2013) were examined using multilevel methods of analysis. The latter study measured the extent to which 
FLM's have the authority to make personal decisions, however, this measure was aggregated to create a company-level variable.

\section{CONCLUSIONS}

Although HRM is an inherently multilevel construct and an increasing number of scholars have been applying multilevel approach to HRM, research in this area has still to reap the full benefits of multilevel thinking (Renkema et al., 2017). The multilevel research in the context of HRM effectiveness is even more undeveloped. Our review of HRM effectiveness research revealed that only few scholars have examined this construct with other variables (antecedences and consequences) at different levels of analysis using multilevel approach. Predominant focus on the organizational level of analysis produced black-box explanations that fail to shed light on the HRM effectiveness on organizational outcomes. To overcome this limitation, a multi-level, behavioral approach that takes into focus the intervening role of the individuals may be implemented. This possibility is given, e.g. by the Ability-Motivation-Opportunity (AMO) framework, which can delineate the psychological mechanisms involved in producing value-relevant employee behaviors (Jiang et al., 2013). Being highly popular, this framework has received inadequate empirical attention, and not yet been advanced to explain how employee behavior actually comes to exist as a response to HRM activities (Foss et al., 2014). Since literature shows that it is not the quantity but the quality or effectiveness of the HRM practices that matters, research on HRM effectiveness in the context of its impact on the individual employees behavior, can be very fruitful. Another way of conducting multi-level research on HRM effectiveness is the issue of increasing the HRM effectiveness through successful implementation of HRM policies and practices. However, there is little shared understanding as to how to achieve this effective implementation. A number of scholars have discussed the responsibility of line managers in implementing HRM practices in their daily work with employees (Bos-Nehles et al., 2013). That is why understanding how their characteristics influence HRM effectiveness may be an important area of future research.

Except from examining antecedents and outcomes of HRM effectiveness at different levels of analysis, research can be conducted where HRM 
effectiveness acts as a moderating or mediating variable. Additionally, some other level (individual, unit) variables could potentially moderate or mediate relationships between HRM effectiveness and its antecedents or outcomes at the organizational level. Moreover, the multilevel considerations regarding HRM effectiveness may relate also to some extended understanding of HRM effectiveness. Renkema et al. (2017) suggest that multilevelity of HRM practices may also relate to (1) HRM system abstraction level (HRM practices being nested in HRM policies which are nested in HRM philosophies), and (2) HRM internalization level (how HRM practices are intended, how they are actually applied, and how they are perceived and routinized by targeted employees). The first suggested approach may be found in the article of Obeidat (2016), and second in the Bos-Nehles et al. (2013).

Conducting multi-level research and analyzing HRM effectiveness by varying its level of analysis, may open up new opportunities for research. The notion of HRM effectiveness can be extended in content to comprise additional or other antecedences and consequences/ outcomes, and applied to other contexts. Utilized at different level of analysis, it may even serve to structure and integrate future research in the HRM - organizational performance field. We hope that this article will stimulate theoretical and empirical research on HRM effectiveness and in consequence contribute to build a coherent model of HRM effectiveness.

\section{REFERENCES}

Aguinis, H., Boyd, B., Pierce, C. \& Short, J. (2011). Walking New Avenues in Management Research Methods and Theories: Bridging Micro and Macro Domains. Journal of Management, 37, 395-403.

Ashkanasy, N. M., Troth, A. C., Lawrence, S. A. \& Jordan, P. J. (2017). Emotions and emotional regulation in HRM: A multi-level perspective. Research in Personnel and Human Resources Management. Bingley, United Kingdom: Emerald Group Publishing, 1-52.

Azmi, F. T. (2011). Strategic Human Resource Management and its Linkage with HRM Effectiveness and Organizational Performance: Evidence from India. The International Journal of Human Resource Management, 22(18), 3888-3912.

Bennett, N., Ketchen, D. J. \& Schultz, E. B. (1998). An examination of factors associated with the integration of human resource management and strategic decision making. Human Resource Management, 37(1), 3-16. 
Bos-Nehles, A., Van Riemsdijk, M. J. \& Looise, J. K. (2013). Employee perceptions of line management performance: Applying the AMO theory to explain the effectiveness of line managers' HRM implementation. Human Resource Management, 52(6), 861-877.

Bowen, D. E. \& Ostroff, C. (2004). Understanding HRM-firm performance linkages: The role of the "strength" of the HRM system. The Academy of Management Review, 29(2), 203-221.

Chang, E. (2005). Employees' Overall Perception of HRM Effectiveness. Human Relations, 58(4), 523-544.

Chew, I. K. H. \& Sharma, B. (2005). The effects of culture and HRM practices on firm performance. International Journal of Manpower, 26(6), 560-581.

Choi, J. H. (2014). Who should be the respondent? Comparing predictive powers between managers' and employees' responses in measuring high-performance work systems practices. International Journal of Human Resource Management, 25(19), 2667-2680.

De Winne, S., Delmotte, J., Gilbert, C. \& Sels L. (2013). Comparing and explaining HR department effectiveness assessments: evidence from line managers and trade union representatives. International Journal of Human Resource Management, 24(8): 1708-1735.

Foss, N. J., Pedersen, T., Reinholt Fosgaard, M. \& Stea, D. (2014). Why Complementary HRM Practices Impact Performance: The Case of Rewards, Job Design, and Work Climate in a Knowledge-Sharing Context. Human Resource Management, 54(6), 955-976.

Gao, Z., Zhang, Y., Zhao, Ch., Li, Ch. \& Wu, Ch. (2016). Expectations, effectiveness and discrepancies: exploring multiple HR roles in the Chinese business context. International Journal of Human Resource Management, 27(10), 1101-1133.

Guenole, N. (2016). The importance of isomorphism for conclusions about homology: A Bayesian multi-level structural equation modeling approach with ordinal indicators. Frontiers in Psychology, 7, 289.

Guest, D. \& Conway, N. (2011). The impact of HR practices, HR effectiveness and a 'strong HR system' on organizational outcomes: a stakeholder perspective. International Journal of Human Resource Management, 22(8), 1686-1702.

Guest, D. E. \& Peccei, R. (1994). The nature and causes of effective human resource management. British Journal of Industrial Relations, 32(2), 219-242.

Han, J., Chou, P. Chao, M. \& Wright, P. (2006). The HR competencies-HR effectiveness link: a study in Taiwanese high-tech companies. Human Resource Management, 45(3), 391-406. 
Harris, K. J., Lambert, A. \& Harris, R. B. (2013). HRM effectiveness as a mediator of the relationships between abusive supervision and technology work overload and job outcomes for technology end users. Journal of Applied Social Psychology, 43, 1686-1695.

Hitt, M. A., Beamish, P. W., Jackson, S. E. \& Mathieu, J. E. (2007). Building theoretical and empirical bridges across levels: Multilevel research in management. Academy of Management Journal, 50(6), 1385-1399.

House, R., Rousseau, D. \& Thomas-Hunt, M. (1995). The meso paradigm: A framework for the integration of micro and macro organizational behavior. Research in Organisational Behaviour, 17(1), 71-114.

Huff, J. \& Schüssler, M. (2016). HRM and the role of internal fit - A systems-behavioral model of HRM effectiveness. Paper presented at the Academy of Management Annual Meeting, August 2016, Anaheim, CA, USA.

Huselid, M. A. (1995). The impact of human resource management practices on turnover, productivity, and corporate financial performance. Academy of Management Journal, 38(3), 635-672.

Huselid, M. A. \& Becker B. E. (1997). The impact of high performance work systems implementation effectiveness, and alignment with strategy on shareholder wealth. Academy of Management Proceedings, 97, 144-148.

Huselid, M. A., Jackson, S. E. \& Schuler, R. S. (1997). Technical and strategic human resource effectiveness as determinants of firm performance. Academy of Management Journal, 40(1), 171-188.

Jiang, K., Lepak, D., Hu, J. \& Baer, J. (2012). How Does Human Resource Management Influence Organizational Outcomes? A Meta-Analytic Investigation of Mediating Mechanisms. The Academy of Management Journal, 55(60), 1264-1294.

Jiang, K., Takeuchi, R. \& Lepak, D. P. (2013). Where do we go from here? New perspectives on the black box in strategic human resource management research. Journal of Management Studies, 50(8), 1448-1480.

Kane, B., Crawford, J. \& Grant, D. (1999). Barriers to effective HRM. International Journal of Manpower, 20(8), 494-515.

Kim, S. \& Ryu, S. (2011). Social capital of the HR department, HR's change agent role, and HR effectiveness: evidence from South Korean firms. International Journal of Human Resource Management, 22(8), 1638-1653.

Klaas, B. S., Semadeni, M., Klimchak, M. \& Ward, A. K. (2012). High-performance work system implementation in small and medium enterprises: A knowledge-creation perspective. Human Resource Management, 51(4), 487-510.

Kozlowski, S. W. J. \& Klein, K. J. (2000). A multilevel approach to theory and research in organizations: Contextual, temporal, and emergent processes. 
In: K. J. Klein \& S. W. J. Kozlowski (eds.), Multilevel Theory, Research, and Methods in Organizations: Foundations, Extensions, and New Directions (pp. 3-90). San Francisco: Jossey-Bass.

Lepak, D. P. \& Snell, S. A. (1999). The human resource architecture: Toward a theory of human capital allocation and development. Academy of Management Review, 24, 31-48.

Mitsuhashi, H., Park, H. J., Wright, P. M. \& Chua, R. S. (2000). Line and HR executives' perceptions of HR effectiveness in firms in the People's Republic of China. International Journal of Human Resource Management, 11(2), 197-216.

Molina-Azorín, J. F., Pereira-Moliner, J., López-Gamero, M. D., Pertusa-Ortega, E. M. \& Tarí, J. J. (2019). Multilevel research: Foundations and opportunities in management. Business Research Quarterly, https://doi. org/10.1016/j.brq.2019.03.004

Obeidat, S. M. (2016). The link between e-HRM use and HRM effectiveness: an empirical study. Personnel Review, 45(6), 1281-1301.

Perry, E. L. \& Kulik, C. T. (2008). The devolution of HR to the line: Implications for perceptions of people management effectiveness. International Journal of Human Resource Management, 19(2), 262-273.

Pfeffer, J. (1993). Barriers to the Advance of Organizational Science: Paradigm Development as a Dependent Variable. The Academy of Management Review, 18(4), 599-620.

Renkema, M., Meijerink, J. \& Bondarouk, T. (2017). Advancing multilevel thinking in human resource management research: Applications and guidelines. Human Resource Management Review, 27(3), 397-415.

Richard, O. C. \& Johnson, N. B. (2001). Strategic Human Resource Management Effectiveness and Firm Performance. International Journal of Human Resource Management, 12(2), 299-310.

Richard, O. C. \& Johnson, N. B. (2004). High performance work practices and human resource management effectiveness: substitutes or complements? Journal of Business Strategies, 21(2), 133-148.

Rousseau, D. M. (1985). Issues of level in organizational research: Multi-level and cross-level perspectives. Research in Organizational Behavior, 7, 1-37.

Rousseau, D. M. (2000). Multilevel competencies and missing linkages. In: K. J. Klein \& S. W. J. Kozlowski (eds.), Multilevel theory, research, and methods in organizations: Foundations, extensions, and new directions (pp. 572-582). San Francisco, CA, US: Jossey-Bass. 
Ruël, H., Bondarouk, T., \& Van der Velde, M. (2007). The Contribution of E-HRM to HRM effectiveness. Results from a Quantitative Study in a Dutch Ministry. Employee Relations, 29, 280-291.

Ryu, S. \& Kim, S. (2013). First-line Managers' HR Involvement and HR Effectiveness: The Case of South Korea. Human Resource Management, 52(6), 947-966.

Shen J., Messersmith, J. G. \& Jiang, K. (2018). Advancing human resource management scholarship through multilevel modeling. The International Journal of Human Resource Management, 29(2), 227-238.

Teo, S. T. T. (2000). Evidence of strategic HRM linkages in eleven Australian corporatized public sector organizations. Public Personnel Management, 29(4), 557-574.

Teo, S. T. T. (2002). Effectiveness of a corporate HR department in an Australian public sector entity during commercialization and corporatization. International Journal of Human Resource Management, 13(1), 89-105.

Teo, S. T. T., Ahmad, T. \& Rodwell J. J. (2003). HR role effectiveness and organizational culture in Australian local government. Asia Pacific Journal of Human Resources, 41(3), 298-315.

Teo, S. T. T. \& Crawford, J. (2005). Indicators of Strategic HRM Effectiveness: A Case Study of an Australian Public Sector Agency During Commercialization. Public Personnel Management, 34(1), 1-16.

Tsui, A. S. (1990). A multiple-constituency model of effectiveness: An empirical examination at the human resource subunit level. Administrative Science Quarterly, 35, 458-483.

Wang, D. S. \& Shyu, C. L. (2008). Will the Strategic Fir Between Business and HRM Strategy Influence HRM Effectiveness and Organizational Performance. International Journal of Manpower, 29(2), 92-110.

Wang, D. S. \& Shyu, C. L. (2009). The Longitudinal Effect of HRM Effectiveness and Dynamic Innovation Performance on Organizational Performance in Taiwan. The International Journal of Human Resource Management, 20(8), 1790-1809.

Wheeler, A. R., Harris, K. J. \& Harvey, P. (2010). Moderating and Mediating the HRM Effectiveness - Intent to Turnover Relationship: The Roles of Supervisors and Job Embeddedness. Journal of Managerial Issues, 22(2), 182-196.

Wheeler, A. R., Halbesleben, J. R. B. \& Harris, K. J. (2012). How job-level HRM effectiveness influences employee intent to turnover and workarounds in hospitals. Journal of Business Research, 65(4), 547-554.

Wright, P. \& Boswell, W. R. (2002). Desegregating HRM: A Review and Synthesis of Micro and Macro Human Resource Management Research. Journal of Management, 28(3): 247-276. 
Wright, P. \& Haggerty, J. (2005). Missing Variables in Theories of Strategic Human Resource Management: Time, Cause, and Individuals. Management revue. The International Review of Management Studies, 16, 164-173.

Wright, P. \& Nishii, L. H. (2013). Strategic HRM and organizational behaviour: integrating multiple levels of analysis. In: J. Paauwe, D. Guest \& P. Wright, HRM and Performance: Achievements and Challenges (pp. 97-110). Chichester: Wiley.

Wright, P. M, Nyberg, A. J. \& Ployhart, R. E. (2018). A Research Revolution in SHRM: New Challenges and New Research Directions. Research in Personnel and Human Resources Management, 36, 141-161.

Wright, P. \& Ulrich, M. (2017). A Road Well Traveled: The Past, Present, and Future Journey of Strategic Human Resource Management. Annual Review of Organizational Psychology and Organizational Behavior, 4, 45-65.

Wright, P. M., McMahan, G., Snell, S. \& Gerhart, B. (2001). Comparing line and HR executives' perceptions of HR effectiveness: services, roles, and contributions. Human Resource Management, 40, 111-123.

Wright, P. M., McMahan, G. C., McCormick, B. \& Sherman, W. S. (1998). Strategy, Core Competence, and HR Involvement as Determinants of HR Effectiveness and Refinery Performance. Human Resource Management, 37(1), 17-29.

Yang, Ch. \& Lin, C. (2014). Does Technical or Strategic HRM Provide a Better Explanation of Organization Performance? iBusiness, 6, 52-62.

\section{EFEKTYWNOŚĆ ZARZA_DZANIA ZASOBAMI LUDZKIMI Z PERSPEKTYWY WIELOPOZIOMOWEJ}

\section{Abstrakt}

Chociaż udowodniono, że istnieje pozytywny związek między efektywnością zarzadzania zasobami ludzkimi a wynikami organizacji, niewiele wiadomo, dlaczego ta relacja istnieje. Wynika to z koncentracji na poziomie organizacyjnym, zamiast badania behawioralnych aspektów poszczególnych osób w organizacji. Celem prezentowanego artykułu jest wypełnienie luki w badaniach efektywności zarządzania zasobami ludzkimi poprzez zastosowanie podejścia wielopoziomowego. Dokonano przeglądu literatury, aby sprawdzić, w jaki sposób efektywność ZZL powiązano $\mathrm{z}$ innymi zmiennymi w poprzednich badaniach zgodnie z logika wielopoziomowa.

Systematyczny przegląd literatury dotyczył badań empirycznych nad efektywnością zarządzania zasobami ludzkimi, koncentrując się na jej antecedencjach i rezultatach. Wyniki przeglądu literatury wykazały niski poziom wykorzystania wielopoziomowego podejścia do rozważań nad efektywnością zarządzania zasobami 
ludzkimi, jednocześnie wskazując na istnienie istnieje luki w badaniu antecedenzji i rezultatów na poziomie indywidualnym oraz jednostki organizacyjnej i grupy.

Słowa kluczowe: efektywność ZZL, strategiczne zarządzanie zasobami ludzkimi, podejście wielopoziomowe, przegląd literatury 